\title{
Implementation of Primary Team Professional Nursing Practice Methods In Hospital: A Systematic Review
}

\author{
Raras Merbawani*, Asef Wildan Munfadlila \\ STIKes Bina Sehat PPNI Mojokerto,Indonesia \\ Corresponding author: rmerbawani@gmail.com
}

\begin{abstract}
Background: The hospital is a health service organization that provides comprehensive health services that achieve promotive, preventive, curative and rehabilitative aspects for the community. The application of the Professional Nursing Practice Method (MPKP) can illustrate the efforts of various countries to improve the quality of nursing care and the working environment of nurses in hospitals.

Purpose: The purpose of this study was to determine the application of MPKP in hospitals. Methods: This research design uses a literature review, which is a series of studies relating to the method of collecting library data, or research whose research objects are explored through various library information (books, encyclopedias, scientific journals, newspapers, magazines, and documents) from several journals that have been researched by previous researchers who have been screened with inclusion and exclusion criteria using several databases namely google shoolar, lib UI, and SINTA which will be used as a literature review in this study. There are 155 journals according to keywords which are screened into 10 journals according to the theme and analyzed which examines the application of the Professional Nursing Practice Method (MPKP).

Results: The results showed that the implementation of MPKP was in the good category and was more dominant, namely $40 \%$ in the nursing care system. In the application of the maximum Professional Nursing Practice Method (MPKP) and good categories, nurses have to make professional values, professional relationships, management approaches, nursing care systems, and reward compensation systems according to nursing standards by looking at performance and determining the appropriate MPKP model.

Conclusion: The better the implementation of the Professional Nursing Practice Method (MPKP) is carried out, the better the services provided by the hospital to patients.
\end{abstract}

Keywords: Professional Nursing Practice Method (MPKP), Primary Team, Nurse. 
Journal Of Nursing Practice

http://thejnp.org

ISSN: 2614-3488 (print); 2614-3496 (online)

Vol.5 No.1. October 2021. Page.55-64

\section{BACKGROUND}

The hospital is a health service organization that provides comprehensive health services to achieve promotive, preventive, curative and rehabilitative aspects for the community. Therefore, the demand for increased health services is one of the factors that must be considered by nurses. (Udianto, Munif, \& Gustian, 2017). However, nurses are not optimal in implementing the Professional Nursing Practice Model (MPKP). So that the quality of health services is not optimal. The MPKP improvement can illustrate the efforts of various countries to improve the quality of nursing care and the nurse's work environment (Sitorus, 2011). The MPKP system is a framework that defines four elements, namely: standards, nursing processes, nursing education, and the MPKP system. If nurses do not have these values as an independent decision maker, then the purpose of health services in meeting patient satisfaction will not be realized. (Nursalam, 2011)

According to research results from (Lobo, Herwanti, \& Yudowaluyo, 2019). The application of professional nursing care methods in the Kelimutu Room, Komodo Room, and Orchid Room at Prof. Hospital. Dr. W. Z. Johannes Kupang is in the poor category (51.9\%). According to research results from (Dion, Fernandez, \& Paun, 2019) based on the perception of the patients being treated, the Implementation of the MAKP Team - Primary in most inpatient rooms is Good Enough $(86.2 \%)$. However, the implementation of the Primary-Team MAKP carried out by nurses did not meet the normative standards caused by the requirements for the Head of the Room and the Primary Nurses who did not meet the educational qualifications and the number that matched the room needs. The results of the research conducted (Udianto et al., 2017) in the Inpatient Room of Blambangan Hospital Banyuwangi that the implementation of the MPKP team was half good, namely as many as 2 inpatient rooms (50\%) and half as many as 2 rooms (50\%) the implementation was still not good. According to (Yusnilawati, Mawarti, \& Nurhusna, 2019) it is known that the application of the team method at Abdul Manaf General Hospital and Jambi Province Mental Hospital as many as 116 respondents $(58.3 \%)$ assessed the application of the team method as good while 83 respondents $(41.7 \%)$ rated less well.

The development of nursing science is currently experiencing rapid development, including increasing client satisfaction through the professional nursing practice model. Currently, many hospitals are competing to implement MPKP in client management. In fact, sometimes the hospital does not pay attention to the resources it has, so it is often found that the MPKP organizational structure is not running according to their respective job disks. Which means this MPKP is only on paper that is displayed in the room. Of course, this will not have an impact on client satisfaction. (Basuki, 2018)

Since the era of Florence Nightingale, various models of nursing care have been found for clients. Modification of the quantity and quality of personnel and various requirements related to MPKP, namely having various types of modifications according to existing conditions, for example team modification, modification of primary nurses. Efforts to improve the quality of nursing care in hospitals in various countries have developed and implemented MPKP in various ways according to the needs of each hospital. In Indonesia MPKP has been developed and implemented in several government and private hospitals. MPKP can improve the quality of nursing care. (Basuki, 2018)

There is no specific research on the application of the Professional Nursing Practice Method (MPKP) for the primary modification team so that researchers are interested in conducting research on the application of the Professional Nursing Practice Method (MPKP) for the primary modification team, especially the application of the Professional Nursing Practice Method (MPKP) for the primary team at Sidoarjo Hospital. 


\section{Journal Of Nursing Practice}

http://thejnp.org

ISSN: 2614-3488 (print); 2614-3496 (online)

Vol.5 No.1. October 2021. Page.55-64

\section{METHODS}

The method used in this research is library research, which is a series of studies relating to library data collection methods, or research whose research objects are explored through various library information (books, encyclopedias, scientific journals, newspapers, magazines, and documents). Literature review, literature research is research that examines or critically reviews knowledge, ideas, or findings contained in the body of academicoriented literature, and formulates theoretical and methodological contributions to certain topics (Anshori \& Iswati, 2019).

The data collection method used in this research is the documentation method, which is a method of collecting data by searching for or digging up data from the literature related to what is meant in the formulation of the problem, namely the application of the Professional Nursing Practice Method (MPKP). The data that has been obtained from various literatures are collected as a unified document that is used to answer the problems that have been formulated. Data was collected using a journal database through Google Scholar, SINTA, Pubmed, SCOPUS, and lib UI according to the inclusion and exclusion criteria.

\begin{tabular}{|c|c|c|}
\hline Criteria & Inclusion & Exclusion \\
\hline $\begin{array}{l}\text { Populati } \\
\text { on }\end{array}$ & $\begin{array}{l}\text { Journal national and i n ter national } \\
\text { Program which relate the topic of } \\
\text { research the application } \\
\text { of methods Practice Keprawatan Profes } \\
\text { sionals (PNPM) }\end{array}$ & $\begin{array}{l}\text { Journal of } \\
\text { national and inter national who res } \\
\text { earched other than on the } \\
\text { application } \\
\text { of methods Practice Keprawatan Pr } \\
\text { ofessionals (PNPM) }\end{array}$ \\
\hline $\begin{array}{l}\text { Interven } \\
\text { tion }\end{array}$ & $\begin{array}{l}\text { Implementation Methods } \\
\text { of Practice Keprawatan Professionals ( } \\
\text { PNPM) }\end{array}$ & - \\
\hline $\begin{array}{l}\text { Compari } \\
\text { son }\end{array}$ & No no comparison & No no comparison \\
\hline $\begin{array}{l}\text { Outcom } \\
\text { es }\end{array}$ & $\begin{array}{l}\text { Implementation Methods } \\
\text { of Practice Keprawatan Professionals ( } \\
\text { PNPM) in accordance with } \\
\text { the standards of nursing }\end{array}$ & $\begin{array}{l}\text { Do not discuss about } \\
\text { the application of the method } \\
\text { of Practice Keprawat an Profession } \\
\text { als (PNPM) }\end{array}$ \\
\hline $\begin{array}{l}\text { Study } \\
\text { design }\end{array}$ & $\begin{array}{l}\text { Descriptive, analytic correlation, E ks } \\
\text { perimental , Literature } \\
\text { review, study qualitatively etc. }\end{array}$ & - \\
\hline $\begin{array}{l}\text { Year } \\
\text { of publi } \\
\text { cation }\end{array}$ & 2010 and up & Before 2010 \\
\hline $\begin{array}{l}\text { Languag } \\
\mathrm{e}\end{array}$ & Indonesian and English & Apart from Indonesian and English \\
\hline
\end{tabular}

Found 155 journals according to keywords and then selected according to the year of publication there were 89 journals then selection according to title there were 18 journals and the last according to the abstract there were 10 journals reviewed 


\section{Journal Of Nursing Practice}

http://thejnp.org

ISSN: 2614-3488 (print); 2614-3496 (online)

Vol.5 No.1. October 2021. Page.55-64

\section{RESULT}

No Title

Researcher

name

Development of

$\begin{array}{ll}\text { 1. } & \text { a Professional Values Mod } \\ \text { el in Nursing (Kaya \& Boz, } & \text { Kaya and I_lka }\end{array}$ 2017)
- D : Literature review

- $\mathrm{S}$ :-

- V: Professional Values Model

- I : Professional score scale

- A :-

- Professional values and job satisfaction, patient satisfaction, and patient care with an emphasis on awareness of professional

values in nursing. Descriptions of professional values and relevant concepts are expected to mediate an increase in patient satisfaction, nurse job satisfaction, and the quality of nursing care. In PVM, the relationship of professional values with job satisfaction has been described and the responsibilities for increasing patient satisfaction, nurse job satisfaction, and access to high-quality nursing care have been described. Literature data reveals that the high professional values of nurses are important factors that increase job satisfaction and the quality of nursing care along with patient satisfaction with the nursing care they receive. Future research based on PVM can reveal whether the model helps nurses to offer more effective care and increase patient satisfaction and nurse job satisfaction. Using the model in further studies with different samples and cultures will make a great contribution to the evaluation of PVM functionality. Future data with PVM in different cohorts with different cultures are expected to make a great contribution to the evaluation of PVM functionality.

Value of

Professional Nurses and S udent Nurses : study comp

2. arative (Poorchangizi,

Borhani, Abbaszadeh,

Mirzaee, \& Farokhzadian, 2019)

Professional nursing values

Concept analysis (Bonnie

J. Schmidt PhD, RN \&

McArthurMLIS, 2017)
Batool Poorcha

ngizi , Fariba B

orhani,

Abbas Abbasza

deh, Moghadd

meh Mirzaee an

d Jamileh Farok

hzadian

Bonnie J.

Schmidt PhD

$\mathrm{RN}, \mathrm{CNE}$

\& Erin

C. McArthurM

LIS
- D : descriptive-analytic crosssectional

- $\quad$ S : Random sampling

- V: Professional values

- I : Questionnaire

- A : Descriptive statistics

- D : Literature review

- $\mathrm{S}:-$

- V: The value of professional nursing

- I : Professional score scale

- A :-

The relationship between experience and the development of professional values is less clear. Although nurses had more experience, they did not have a significantly higher mean NPVS-R compared to nursing students. This indicates educational and clinical deficiencies, which leads to inadequate promotion of professional values. Faculty members and hospital managers can dramatically develop the professional values of nursing students and nurses by focusing on inculcating professionalism and activism. - A working definition of professional nursing values is presented as professional nursing principles of human dignity, integrity, altruism, and fairness that serve as a framework for standards, professional practice, and evaluation. This definition is consistent with the code of ethics and research findings 3.45 and supports the existence of the general values expressed in the nursing code of ethics. This code of conduct can be a starting point for a 
better understanding of this important concept. Existing caring theories can guide examination of the attribute relationships that define professional nursing values to explore whether these are dimensions of the overarching value of caring.

- The majority of respondents stated that the method of providing nursing care 53 people $(52 \%)$ was not effective, while

Overview of the Application of

Professional Nursing

4. Practice Models

According to the

Implementing Nurses at

Irna B RSUP Fatmawati

Jakarta (2012)
Beautiful

Sholihati

- D : descriptive with cross

sectional

- S: Disproportionate Stratified

Random Sampling

- $\quad \mathrm{V}$ : implementation of MPKP

- I : questionnaire

- A: Chi square other respondents stated that it was effective 49 people $(48 \%)$. The distribution of respondents based on professional values, the majority said 68 people $(66.7 \%)$ were good, while $34(33.3 \%)$ respondents said they were not. The distribution of respondents based on professional relationships, the majority said 58 people $(56.7 \%)$ were good, 44 people $(43.1 \%)$ said they were not. The distribution of respondents regarding the nursing management approach, the majority said $54(52.9 \%)$ were good, and $44(43.15)$ respondents said they were not. Respondents' opinion about the compensation and reward system, 51 people $(50 \%)$ said they were satisfied, and other respondents said 51 people $(50 \%)$ were not satisfied, the compensation and reward system was balanced.

Analysis of the Implementation

5. of Professional Value Nurs ing at a Jakarta referral hospital

Rutmauli Hutag aol , Hanny $\mathrm{Ha}$ ndiyani , Nurdi ana
- $\quad$ : qualitative case study

- $\quad$ S : 517

- V: implementation of

professional values

- I: questionnaire (professional value scale)

- A : describes the gaps found

- D : qualitative with case study approach

Implementation of the

La ode Syaiful

Professional Nursing

Islamy, Zainul

Practice Model at the

Abidin, Rinita

Andriani,

Bauba City Hospital (2019) $\quad \begin{aligned} & \text { Andriani, } \\ & \text { Henni Arisanti }\end{aligned}$
- $\mathrm{S}:-$

- V : implementation of MPKP

- I : interview and observation

- A : data reduction, data presentation, and conclusion drawing
- $\mathrm{H}$ acyl scale score of professionals average nurse is said to be quite strong. Of the

26 question items categorized into three professional values of nurses. The highest result in professional values is trust while the lowest is professional. The application of all professional values

is still lacking, especially by nursing leaders

- The results showed that in terms of the structure of the professional nursing practice model (MPKP) from all stages of the professional nursing practice model (MPKP) which were carried out well, only team formation and Hand Over, while pre conference, post conference and nursing rounds were not carried out properly. In terms of the process of implementing the professional nursing practice model at the Baubau City Hospital using the team modified primary nursing method but it is not in accordance with the standards because there are still limited human resources, both team leaders and members who have insufficient nursing education. 
- In terms of the application of professional values, it has been implemented well, such as treating patients well, the patient's family as partners and respecting the patient's

autonomy. Professional values that have not been implemented at the Baubau City Hospital are poor communication techniques from nurses who carry out nursing actions, sometimes

miscommunication occurs between nurses and patients or their families.

- The application of the Professional Nursing Practice Model (MPKP) with the Hoffart and Woods concept approach in the Class III Inpatient Room BLUD Cut Nyak Dhien Meulaboh Hospital was in the appropriate category as much as $60 \%$, the implementation of

Application of the

Professional Nursing

7. Practice Model at Cut

Nyak Dhien Hospital

(2018)
Kesuma

Atmaja, Hajjul

Kamil
- S : Total sampling

- V : Implementation of MPKP

- I : Questionnaire

- A : Descriptive analysis
- D : Cross sectional professional values in the application of MPKP in the appropriate category was $73.8 \%$, Implementation of professional relations in the application of MPKP in the appropriate category as much as

$78.8 \%$, Implementation of the management approach in the application of MPKP in the appropriate category as much as $76.3 \%$, Implementation of compensation and rewards in the application of MPKP in the inappropriate category as much as

$85.0 \%$. Implementation of the method of providing nursing care in the application of MPKP in the inappropriate category as much as $78.8 \%$

- The results of the univariate analysis based on professiona values showed that the application of professional values in the good category was $56.5 \%$ and the poor category was $43.5 \%$.

- The univariate results based on the management approach are known to apply the management approach with a good category of $50.4 \%$ and a poor category of $49.6 \%$,

the Application of

- D : cross sectional

- S: simple random sampling

- V : implementation of MPKP,

level of patient satisfaction

- I : Questionnaire

- A : chi square

- Univariate results based on the nursing care system found that the implementation of the nursing care delivery system was in the good category of $53.9 \%$ and the poor category of $46.1 \%$,

- Univariate results based on the application of professional relations are known to be in the good category of $60.9 \%$ and the bad category of $39.1 \%$

- The univariate results based on the compensation and reward system show that the application of professional relations is in the good category by $60 \%$ and the unfavorable category by $40 \%$ 
Journal Of Nursing Practice

http://thejnp.org

Overview of the

Implementation of the

9. Professional Nursing

Hospital. Moewardi

Surakarta (2018)
Fitria Felia

- D : quantitative with simple descriptive

- $\quad$ S : total sampling

- V : implementation of mpkp

- I : questionnaire

- A: univariate
- An overview of the implementation of the professional nursing practice model in the hospital. Dr. Moewardi Surakarta, who used the modified primary team method, was mostly categorized in good condition. The description of the implementation of the professional nursing practice model is seen from the nurse's performance, namely from 33 respondents 22 $(66.7 \%)$ categorized as good and $11(33.3 \%)$ categorized as adequate, the implementation of nursing care documentation from 33 respondents $26(78.8 \%)$ respondents categorized as good and 7 $(21.2 \%)$ respondents were categorized as moderate, the work motivation of nurses was categorized as high with a percentage of $78.8 \%$ and the satisfaction achieved by nurses could also be categorized as satisfied with a percentage of $57.6 \%$

Application of Lewin's Cha nge Management Model fo r Optimizing Management

10. Functions in Nursing Dele ation between Head Nurses and TEAM Leaders at Jak arta Military Hospital
- Implementation of the process

of devolution at home sick military Jakarta has not

been optimal, can be

caused by several things that researchers have perform the

analysis by using the diagram to the bones of

fish and find some problems 
Journal Of Nursing Practice

http://thejnp.org

ISSN: 2614-3488 (print); 2614-3496 (online)

Vol.5 No.1. October 2021. Page.55-64

DISCUSSION

The results of the analysis of 10 journals $9(90 \%)$ from 10 journals stated that the application of Professional Nursing Practice Methods was in the good category and $1(10 \%)$ of 10 journals stated that the Application of Professional Nursing Practice Methods had been implemented but not in accordance with nursing standards.

The results of the analysis of 10 journals there are 6 journals which state that in the application of the Professional Nursing Practice Method (MPKP) is more dominant with professional values. The results of research from (Sholihati, 2012) which is entitled Overview of Professional Nursing Practice Model Demanding Nurse Practitioners in Irna Room B Fatmawati Hospital Jakarta, the majority of respondents stated that the method of providing nursing care 53 people (52\%) was not effective, while other respondents stated it was effective 49 people ( $48 \%$ ). Distribution of respondents based on professional values, the majority said 68 people $(66.7 \%)$ were good. Distribution of respondents based on professional relationships, the majority said 58 people $(56.7 \%)$ were good. The distribution of respondents regarding the nursing management approach, the majority said 54 (52.9\%) were good. Respondents' opinion about the compensation and reward system, 51 people $(50 \%)$ said they were satisfied, and other respondents said 51 people $(50 \%)$ were not satisfied, the compensation and reward system was balanced.

Professional values are the core of the Professional Nursing Practice Model, which includes: intellectual values, moral commitment, autonomy, control and accountability (Sitorus, 2011). This study is similar to research from (Wati, Ernawaty, \& Nurju'ah, 2011) entitled Analysis of the Implementation of Nursing Services in the Murai I and Murai II Rooms at RSud Arifin Achmad, Riau Province, which proves that professional values are more dominant with the results of the analysis of the relationship between values. Professional value with the implementation of the provision of nursing services obtained that there are 10 nurses $(83.3 \%)$. So the researcher assumes that there is a statement that confirms that professional values are the main component in a professional nursing practice, with proven results that are dominant in good professional values, it is very easy to implement the Professional Nursing Practice Method (MPKP) in accordance with nursing standards.

The results of the analysis of 10 journals, there are 2 journals which state that the application of the Professional Nursing Practice Method (MPKP) is more dominant in the nursing care documentation system. The results of research from (Feliya, 2018) entitled Overview of the Implementation of the Professional Nursing Practice Model at Dr. Hospital. Moewardi Surakarta, with the results of the implementation of nursing care documentation from 33 respondents $26(78.8 \%)$ respondents were categorized as good.

In an effort to improve service quality, in providing nursing care, all nursing staff absolutely apply nursing care standards (Depkes, 2011). The method of providing nursing care, the system of providing nursing care has the meaning of an assignment for nurses who are used in providing nursing practice services to clients. The method describes the organization's philosophy, structure, workforce and client patterns. In the development of nursing towards professional services, several methods of providing nursing care are used, such as case, functional, team and primary nursing methods. In professional nursing practice, the most possible method of providing professional nursing care is the nursing method that uses primary nursing (Basuki, 2018). This study is similar to (Kasim \& Abdurrouf, 2016) entitled Improving the Quality of Services and Documentation of Nursing Care Using the Team Method, the implementation of nursing care documentation from 33 respondents 26 (78.8\%) respondents categorized as good and $7(21.2 \%)$ respondents categorized as sufficient. So the researcher assumes that the application of nursing care greatly affects the 


\section{Journal Of Nursing Practice}

http://thejnp.org

ISSN: 2614-3488 (print); 2614-3496 (online)

Vol.5 No.1. October 2021. Page.55-64

implementation of the Professional Nursing Practice Method (MPKP) so that if the nursing care system does not work well and in determining the model of care it is not appropriate, it will have an impact on the implementation of the MPKP in accordance with nursing standards or not in accordance with nursing standards. .

The results of the analysis of 10 journals, there are 2 journals which state that the application of the Professional Nursing Practice Method (MPKP) is more dominant in professional relationships. The results of research from (Atmaja \& Kamil, 2018) entitled Application of Professional Nursing Practice Model at Cut Nyak Dhien Hospital, the implementation of professional values in the application of MPKP in the appropriate category is $73.8 \%$, the implementation of professional relations in the application of MPKP in the appropriate category as much as $78.8 \%$, implementation of the management approach in the application of MPKP in the appropriate category as much as $76.3 \%$, implementation of compensation and rewards in the application of MPKP in the inappropriate category as much as $85.0 \%$. Implementation of the method of providing nursing care in nursing the application of MPKP in the inappropriate category was $78.8 \%$.

Professional relationships, professional relationships are needed between nurses and other health practitioners. The provision of health care to clients is provided by several members of the health team. But has a focus on providing health care to clients. Because many members of the health team are involved, agreement is needed on how to carry out this collaborative relationship. This relationship occurs through the client documentation system, watch duty operations, initial and final conferences and case discussions (Sitorus, 2011). This study is similar to the study (Sirait, 2012) entitled The Relationship between the Application of Beginner MPKP with the Job Satisfaction Level of Nurses and Doctors in the Beginner MPKP Room at PGI Cikini Hospital, Jakarta, which is more dominant in the application of professional relations with a good category of $60.9 \%$. So the researcher assumes that with the dominance of good professional relationships and very good professional relationships in the nursing care process, if the professional relationship is good, the nursing care system is also good, so that this relationship will bring two results at once in accordance with a good percentage of achievement.

\section{CONCLUSSION}

From the results of research journals that have analyzed the application of the Professional Nursing Practice Method (MPKP) it is said to be good by looking at 5 indicators, namely professional values, professional relationships, management approaches, nursing care systems, and reward compensation systems. The results of the analysis of all journals prove that the application of the Professional Nursing Practice Method (MPKP) is in the good category, with $6(60 \%)$ of the dominant journals with the application of professional values, $2(20 \%)$ of the 10 dominant journals with the application of nursing care, and $2(20 \%)$ of the dominant journals with the application of professional relations. The better the implementation of the Professional Nursing Practice Method (MPKP) is carried out, the better the services provided by the hospital to patients.

\section{REFERENCES}

Anshori, M., \& Iswati, S. (2019). Metode Penelitian Kuantitatif. Surabaya: Universitas Airlangga Press.

Atmaja, K., \& Kamil, H. (2018). Penerapan Model Praktek Keperawatan Profesional Di Rumah Sakit Cut Nyak Dhien. Keperawatan.

Basuki, D. (2018). Buku Ajar Manajemen Keperawatan (1st ed.). Sidoarjo: Indonesia Pustaka. 


\section{Journal Of Nursing Practice}

http://thejnp.org

ISSN: 2614-3488 (print); 2614-3496 (online)

Vol.5 No.1. October 2021. Page.55-64

Bonnie J. Schmidt PhD, RN, C., \& McArthurMLIS, E. C. (2017). Professional Nursing Values: A Concept Analysis. Whiley, Nursing Forum an Independent Voice of Nursing.

Depkes, R. . (2011). Instrumen evaluasi penerapan standar asuhan keperawatan. Jakarta: Kemenkes RI.

Dion, Y., Fernandez, H. A., \& Paun, R. (2019). Hubungan Implementasi Model Asuhan Keperawatan Profesional (MAKP) TIM - PRIMER dengan Mutu Pelayanan Keperawatan di Ruang Rawat Inap RSUD DR. BEN MBOI RUTENG. CHMK NURSING SCIENTIFIC, VOLUME 3 N(p-ISSN : 2621-4091), 89-101.

Feliya, F. (2018). Gambaran Pelaksanaan Model Praktik Keperawatan Profesional Di Rumah Sakit Dr. Moewardi Surakarta. Jurnal Keperawatan.

Kasim, M., \& Abdurrouf, M. (2016). Peningkatan Kualitas Pelayanan Dan Pendokumentasian Asuhan Keperawatan Dengan Metode Tim. Nurseline Journal No. 1, vol 1(ISSN 2540-7937).

Kaya, A., \& Boz, I. (2017). The Development of The Professional Values Model in Nursing. Nursing Ethics, 1-10.

Lobo, Y., Herwanti, E., \& Yudowaluyo, A. (2019). Hubungan penerapan metode asuhan keperawatan profesional (makp) dengan kinerja perawat di ruang kelimutu, ruang Komodo, dan ruang anggrek rsud prof. Dr. W. Z. Johannes kupang. CHMK NURSING SCIENTIFIC, 3 nomor 2(P-issn : 2621-4091 e-: 2580-9784), 126-132.

Nursalam. (2011). Manajemen Keperawatan (3rd ed.). Jakarta: Salemba Medika.

Poorchangizi, B., Borhani, F., Abbaszadeh, A., Mirzaee, M., \& Farokhzadian, J. (2019). Professional Values of Nursing Student: A Comparative Study. BMC Medical Education.

Sholihati. (2012). Gambaran Model Praktik Keperawatn Profesional Menutut Perawat Pelaksana di Ruang Irna B RSUD Fatmawati Jakarta.

Sirait, Y. (2012). Hubungan Penerapan MPKP Pemula dengan Tingkat Kepuasan Kerja Perawat dan Dokter pada Ruangan MPKP Pemula di RS PGI Cikini Jakarta.

Sitorus, R. \& P. (2011). Manajemen Keperawatan, Mnajemen Keperawatan di Ruang Rawat. Jakarta: S. Sagung. Ed.

Udianto, A. M., Munif, B., \& Gustian, C. I. (2017). Hubungan Penerapan Mpkp Tim Dengan Tingkat Kepuasan Pasien Di Ruang Rawat Inap Rsud Blambangan Banyuwangi. 5 No. 2.

Wati, N. L., Ernawaty, J., \& Nurju'ah. (2011). Analisa Pelaksanaan Pemberian Pelayanan Keperawatan Di Ruang Murai I Dan Murai Ii Rsud Arifin Achmad Provinsi Riau. Jurnal Nurse Indonesia.

Yusnilawati, Mawarti, I., \& Nurhusna. (2019). Hubungan Penerapan Metoda Tim Dengan Kinerja Perawat Pelaksana di RSJD Provinsi Jambi dan RSUD Abdul Manaf Kota Jambi. Jurnal Ilmiah Ilmu Terapan Universitas Jambi, 3(p-ISSN: 2580-2240 eISSN: 2580-2259) 